\title{
MAGNETIC MARKERS USE FOR MONITORING OF ENVIRONMENTAL POLLUTION CAUSED BY FRACTURING FLUIDS DURING SHALE GAS EXPLOITATION
}

\begin{abstract}
Magnetic materials may be added to the fracturing fluid, as the magnetic marker allowing to determine the range and efficiency of hydraulic fracturing. The application of appropriate magnetic markers can significantly improve the efficiency of shale gas extraction. There are, however, other important benefits of magnetic markers use, involving the monitoring of environmental pollution, during gas extraction with above mentioned method. However, with the rapid increase in amount of shale gas extracted using hydraulic fracturing method, there are also credible reports on the possibility of groundwater or the soil pollution. Thus, it is necessary to apply enhanced methods, to effectively detect any fracturing fluid leakage. The use of magnetic markers gives such opportunities. In case of leakage and consequently the fracturing fluid pollution, magnetic markers are placed into the soil environment. The presence of pollutants in soil can be detected using a number of standard chemical methods, but magnetometric ones, which are much faster and cheaper deserve special attention, because they enable in-situ detection of the magnetic marker in fracturing fluid leakage. This article discusses the above-mentioned issues based on the literature review, the knowledge and experience of the authors.
\end{abstract}

Keywords: magnetic markers, shale gas, hydraulic fracturing, environmental pollution, magnetometric methods, magnetic susceptibility

\section{Shale gas}

As a consequence of high prices of energy resources and fluctuations of its prices, there are a variety of activities carried out in many countries, to ensure independence from imported raw materials and resources, and thereby guarantee

\footnotetext{
${ }^{1}$ Autor do korespondencji / corresponding author: Jan Bogacki, Faculty of Building Services, Hydro and Environmental Engineering, Warsaw University of Technology, Nowowiejska 20, 00-653 Warsaw, tel. 222345423, jan.bogacki@is.pw.edu.pl

2 Jarosław Zawadzki, Faculty of Building Services, Hydro and Environmental Engineering, Warsaw University of Technology, Nowowiejska 20,00-653 Warsaw, j.j.zawadzki@gmail.com
} 
energy safety. Among the alternative energy sources, shale gas is mentioned. Gas combustion is more environmentally friendly than oil [43]. Shale gas is natural gas, which is trapped in the shale bedrock. The shale gas deposits are in many places in the world, among the others in the United States, China and Poland [19]. The process of industrial exploitation began only about 30 years ago $[12,22]$. Shales are rocks with low porosity, what makes the process of shale gas migration considerably limited, preventing the use of shale gas as an industrial energy source. In order to increase the extraction of shale gas, it is necessary to increase the permeability of the bedrock. This is achieved using a hydraulic fracturing technology.

\section{Hydraulic fracturing}

Hydraulic fracturing is a process that increase the efficiency of the well. The process involves the hollow vertical well on the depth of the bed and a series of horizontal wells in order to penetrate it. Horizontal wells are loaded with explosives, which are then detonated. Sharp pressure pulses appearing as a result of the explosion creates tiny cracks, fractures, in the bedrock. Then the fracturing fluid is injected into the fractures.

The main component (98 - 99.5\%) in most of the used fracturing fluids are water and proppant. Water is used in the process for a short time, however, it is used in a big amount, up to $20000 \mathrm{~m}^{3} /$ well [23]. The aim of the proppant use is to prevent the closure of created fractures, due to rock pressure [24]. Proppant has to have adequate mechanical strength, increasing with the depth of shale. In addition, the diameter of the proppant should be small enough, so that it can penetrate into the fractures - the maximum grain diameter is considered as about $2 \mathrm{~mm}$.

Some chemical additives $(0.5-2 \%)$ are added to the fracturing fluid. Many of them are characterized by significant toxicity [42]. Chemical additives used in fracturing fluid improve the fracturing process. Additives are used: to prevent the swelling of clays (e.g. diethylamine hydrochloride, sodium or potassium chloride), to prevent corrosion of pipes in a wellbore (isopropanol, methanol, chlorobenzene), to prevent stone settling (polyethylene glycol), to prevent precipitation of metal oxides (citric acid), allowing formation of a suspension of sand in water (guar gum, hemicellulose), allowing the subsequent breakdown of gelling agents, responsible for forming a suspension of sand in water (ammonium persulfate), for maintaining a neutral $\mathrm{pH}$, for the proper operation of gelling agents (potassium carbonate), cleaning and disinfecting borehole (glutaral aldehyde, ammonium chloride), maintaining the proper viscosity of the liquid, with increasing temperature (borate salts, isopropanol), for reducing friction (petroleum distillates ), acids (hydrochloric acid).

The compositions of the fracturing fluids differ depending on the manufacturer, the country of use and the borehole depth. Proper selection of the fractur- 
ing fluid composition, including, but not limiting quantities and parameters of proppant, can have a crucial influence on the fracturing process economic viability [46]. The fracturing fluid after fracturing process is pumped from the well. A returned fluid, so called flowback fluid, have usually different chemical composition and lower volume, compared to the fracturing fluid injected into the ground [36]. Changes in the chemical composition are due to the partial consumption of chemical additives in the fracturing process, leaving some portion of fluid with proppant in borehole or with draining from the well a quantity of highly saline groundwater as well as a variety of other contaminants depending on local geology.

Exploitation of shale gas using hydraulic fracturing method is a process causes much controversy. Among the most important problems, above all, the possibility of water and soil pollution, as well as a large water consumption [36] are indicated. Exploitation of shale gas will transform the area into a heavy industrial zone, which is characterized by considerable pressure on the environment $[2,27,44]$. Therefore, in many countries, studies of hydraulic fracturing have been significantly decreased, and in 2011, France was the first country that introduce a legal prohibition of hydraulic fracturing.

Shale gas may be a rich potential source of energy and because of that research on alternative to hydraulic fracturing method $[17,35]$ are developed. In addition, research on improving and increasing safety of hydraulic fracturing are carried out.

\section{Magnetic marker}

Proper fracturing is crucial for shale gas technology. The greater is the range of fracturing and the greater is the amount of fractures that after process remains open, the greater will be the amount of the received gas. Therefore, from an economic point of view, the most important is the estimation of fracturing range [6]. For this purpose, the use of easily detectable marker, added to the fracturing fluid, is considered.

Many materials, such as radionuclides $[1,15]$ may be considered as a potential marker used during hydraulic fracturing. Because of the widespread use, a potential marker has to meet a number of even contradictory criteria, inter alia, it has to be both cheap and environmental safe. For this reason, many materials, including the aforementioned radionuclides can't be used.

Requirements for potential marker can be met by a magnetic material, a substance which is active in both natural and anthropogenic magnetic fields $[11,49,50]$. In the case of a magnetic marker usage in hydraulic fracturing, range may be calculated on the basis of the respective magnetic measurements before and after the fracturing $[9,28]$. Currently, it is believed, that a potential marker should be a soft magnetic material with high magnetic susceptibility and low coercivity $[49,50]$. 
Potential materials are considered to be: natural magnetic materials, e.g. magnetite, ferrites, ferrofluids or nanomaterials $[3-5,7,8,10,11,13,21,26,29$, $31,34,45,49-51]$. The use of magnetite is associated with the risk, due to the lack of repeatability of its magnetic properties and low mechanical resistance. An alternative to the magnetite, may be its synthetic counterparts, so-called "soft" ferrites. Ferrites are commonly used in electrical engineering, among others, as the cores of the coils. Among the ferrites for the best candidates to be markers in hydraulic fracturing $\mathrm{Zn}, \mathrm{Mn}$ and Ni ferrites [49, 50] are considered. It can be expected, that the magnetic properties of nanoferrites [51], due to superparamagnetism phenomena, would be better than in the case of conventional ferrite with several micrometers grain diameter [49]. Unfortunately, despite the clearly superior magnetic properties, main drawback of magnetic nanomaterials use is their very high price, reaching even $13600 \$ / \mathrm{kg}$ [29]. The cost of single fracturing with magnetic nanomarker can be then up to 3 billion $\$ /$ well [29]. In the case of ferrofluid (liquid made of ferromagnetic particles with size of a few to dozens nanometers, suspended in a dispersing fluid, which is usually water, mineral oil, synthetic oil, hydrocarbons or fluorohydrocarbons [16]), it can be expected, that the price doesn't have to be as high as in case of nanoferrites. However, a factor that prevents their widespread use in hydraulic fracturing is too small ferrofluid durability in extremely difficult chemical and geological fracturing conditions.

As mentioned above, it now seems, that the best material, that meets the requirements for a potential marker magnetic are "soft" ferrites. However, due to insufficient mechanical strength of the magnetic marker, ferrite can't easily replace the conventional proppants in the fracturing fluid. However, it is possible to produce magnetic-proppant composite, performing both the roles of the proppant and the magnetic marker. Currently, research on obtaining the magnetic proppants, involves a great interests.

\section{Fracturing fluid environmental pollution}

Hydraulic fracturing is a multistep process. During each of these stages, leakage may exist and consequently, the penetration of the fracturing fluid into the water and soil environment may happen. The most serious fracturing fluid leakage consequences can be: during its preparation and storage, during the introduction into the wellbore, during pumping the flowback fluid from wellbore and also during treatment and disposal of flowback fluid.

As a result of the leakage, fracturing fluid and all of its components are introduced into environment. Environmental threat is associated with the amount of fluid introduced into the environment and the chemical compounds - the components of the fracturing fluid [44]. The environmental pollution range can be determined with a number of conventional chemical laboratory methods. However, due to considerable time-consuming and cost ineffectiveness of chem- 
ical laboratory methods, much faster and cheaper magnetic measurements methods, especially magnetometeric ones, deserves special attention. Magnetic measurements allow for easy detection of the magnetic marker, also in the field, in the case of fracturing fluid environmental pollution.

\section{Magnetometry}

Magnetometry is a surface, noninvasive geophysical method in which the object of measurement is magnetic susceptibility [25]. It is sufficiently accurate method to detect magnetic anomalies caused by both natural and anthropogenic factors, resulting from the accumulation of magnetic particles. This method was originally used primarily to assess the precipitation of municipal and industrial dust onto the surface layers of soil and sludge. Dusts containing magnetic particles are emitted into the atmosphere from a variety of pollution sources, and then deposited in the surface layer of soil [14, 37-42, 48]. These particles of anthropogenic origin, can be relatively easily detected, due to their magnetic properties by magnetometric methods. One of field magnetometric measurement devices is shown in Fig. 1.

Today, the spectrum of field magnetometry applications, due to advantages of the method, is rapidly expanding. It should be noted, however, that although soil magnetometry is a fast and inexpensive geophysical alternative to timeconsuming and expensive laboratory tests, it requires a lot of experience in practical use $[25,39,48,52]$.

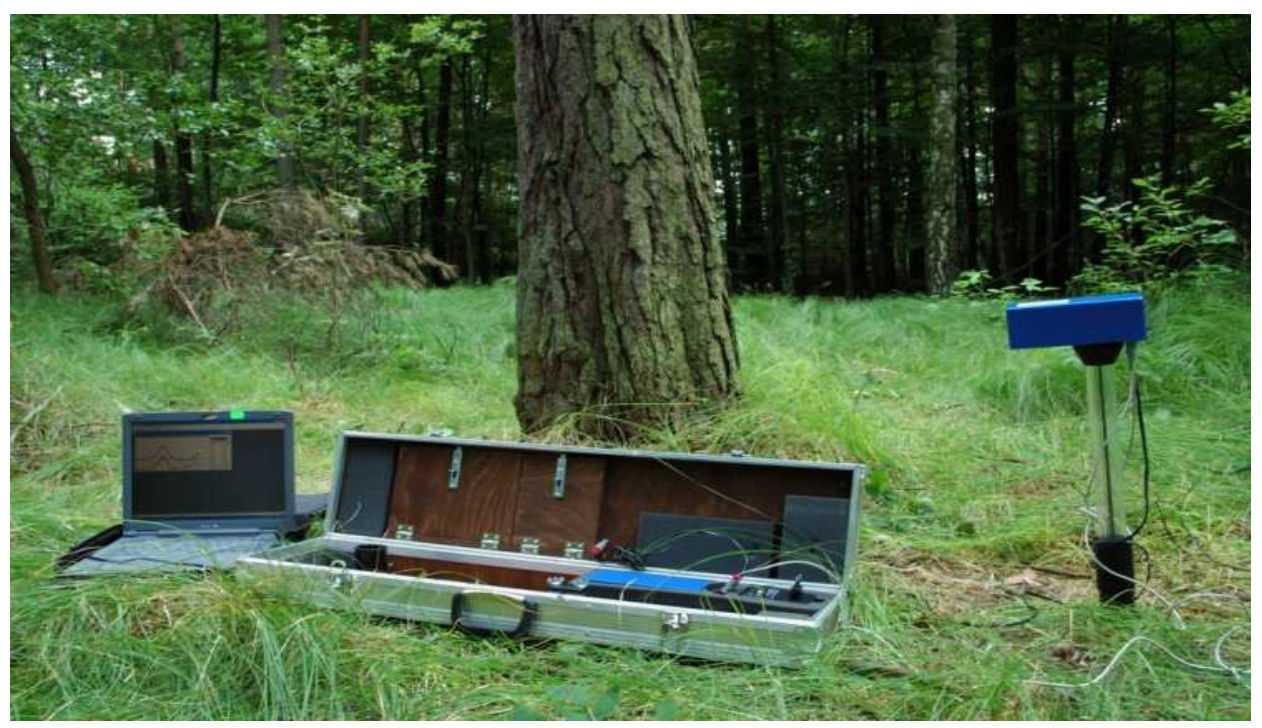

Fig. 1. Magnetic susceptibility measurements in soil profile with SM-400 device

Rys. 1. Pomiar podatności magnetycznej w profilu glebowym miernikiem SM-400 


\section{Magnetometric methods use for fracturing fluid environmental pollution monitoring}

In the case of using magnetic marker during hydraulic fracturing to determine the range of fracturing, the same marker can be also used to determine the possible water and soil environmental pollution with the fracturing or flowback fluid.

Magnetometric measurements should be performed in the immediate vicinity of the planned well and in the fracturing fluid transport corridor. The proposed density of the measuring grid, should be appropriately matched to the local conditions and their spatial variability to obtain reliable values of the magnetic background, prior to the exploitation of shale gas. In order to control the fracturing fluid pollution level, the following magnetometric monitoring scheme is proposed:

- Preliminary measurements, before any fracturing-related works, in order to determine the geochemical magnetic background,

- Control measurements, during the drilling, indicating the potential impact of excavated material on the soil surface layer,

- Control measurements, after the completion of the drilling and removal of all equipment and drilling installations,

- Measurements after hydraulic fracturing and removal of the flowback fluid,

- Final measurements at the end of exploitation and land reclamation.

Magnetometric measurements can be performed either using a portable field magnetometer, as well as the use of laboratory magnetometers $[14,25,39$, 52 ], based on field collected soil cores with the use of e.g. HUMAX probe. Exemplary field magnetometric measurements are shown in Fig. 2.

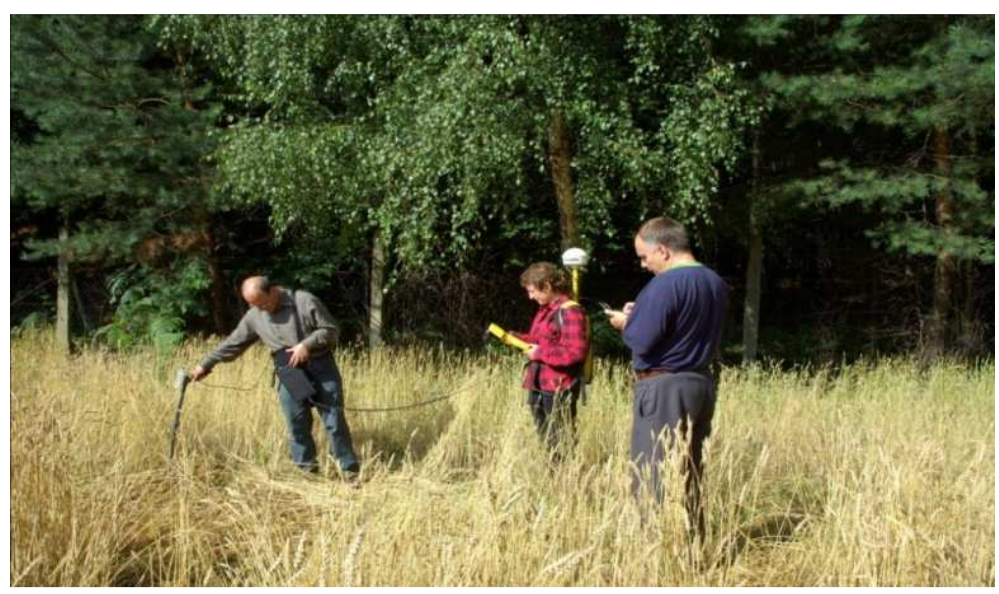

Fig. 2. Magnetometric monitoring by means of MS2D Bartington gauge

Rys. 2. Monitoring magnetometryczny gleby za pomocą miernika MS2D Bartington 
After each stage measurement should be done, to determine spatial distribution of the measured parameters. Calculations using specialized statistical and geostatistical software should be performed in order to monitor changes in soil's spatial magnetic parameters during the exploitation of shale gas. Based on the high density grid, soil magnetic susceptibility high-resolution spatial distribution can be estimated by means of selected GIS (Geographic Information System) [33] or geostatistical methods, including those that enable the integration of data from various sensors (co-kriging, co-simulation) [47, 48]. In addition to the soil magnetic susceptibility spatial distribution, maps of probability, showing the probability of exceeding a critical concentration of magnetic markers associated with soil contamination, may be created. For areas within creased soils magnetic susceptibility or calculated high probability of contamination, it is proposed to perform further (secondary) measurements, using e.g. GRAD 601-2 magnetometer, with a maximum penetration depth $200 \mathrm{~cm}$. Fast and precise magnetic susceptibility measurements in soil profiles may be also achieved by using a SM400 sensor. Therefore, it may be also used, to determine the three-dimensional spatial distribution of the magnetic markers in the whole soil layer near the shale gas well. Thanks to above-mentioned advantages of magnetometric methods the spatial distribution of soils magnetic susceptibility could be determined often as desired, that allows the spatiotemporal analysis of soil contamination, at the shale gas exploitation site.

\section{Polluted soil and flowback fluid treatment}

There are many conventional methods of contaminated soil remediation and wastewater treatment, that does not require the use of magnetic markers. These methods, however, are very often associated with the formation of large quantities of wastes or introduction into the effluent considerable amounts of salts.

The use of magnetic markers to determine the possible pollution of soil, can also be useful for the of flowback fluid treatment [20]. When the fracturing fluid comprises a ferrofluid, strong external magnetic field might be applied to separate magnetic particles from the flowback fluid [18]. In a similar way, magnetic proppant unused during the fracturing process can be recovered from the flowback fluid. After separation and cleaning, it could be returned for re-fracturing, with a new portion of fresh fracturing fluid.

Magnetic particles e.g. ferrites or magnetite, could also be used for the flowback fluid treatment. The magnetic particles could be used primarily to remove heavy metals and radionuclides [18]. For this purpose, adsorption processes on the surface of the magnetic material would be used.

Another mechanism that may be used for treatment, are catalytic properties of iron compounds contained in the magnetic materials. In this case two catalytic mechanisms could be considered. The first one is heterogeneous catalysis mechanism, due to the presence of the solid magnetic phase dispersed in treated flow- 
back fluid. On the surface of the solid phase, several processes involving: oxidation and reduction of pollutants and metal catalyst, precipitation and coprecipitation the hydrated metals oxides and hydroxides, adsorption and coagulation [32], will overlap. The second ongoing mechanism is the homogeneous catalysis. Dissolved in the acidic environment iron-containing minerals, released $\mathrm{Fe}^{2+}$ ions to the solution, becomes a Fenton/pseudo-Fenton reaction activator [30].

\section{Conclusions}

Magnetic materials added to proppants, may act as the magnetic marker during the hydraulic fracturing process, enabling to determine the extent of fractures. In the case of leakage and consequently fracturing fluid pollution, magnetic markers added to fracturing fluid will be introduced into the soil environment. Therefore, the presence of magnetic markers in the soil and thus the other components of the fracturing fluid, could be determined by magnetometric methods, which are much cheaper and faster than the traditional laboratory chemical ones.

Application of magnetometric methods, will allow to determine precisely the area of fracturing fluid leakage. Moreover, thanks to its soft magnetic properties, the magnetic marker could be separated from the flowback fluid by application of external magnetic field, thereby making possible magnetic marker reuse in other fracturing, that decrease costs of the process. In addition, the catalytic properties of the magnetic marker, could be used for flowback fluid treatment, using heterogeneous and homogenous Fenton/pseudo-Fenton catalytic mechanisms.

\section{Acknowledgment}

This work was supported by the Polish National Research and Development Center (NCBiR) under grant: BLUE GAS II, EMPROP: Electromagnetic method to estimate penetration of proppant in the fracturing process.

\section{Literature}

[1] Attendorn HG., Bowen R.: Radioactive and Stable Isotope Geology, Chapman \& Hall, London, 1997.

[2] Baranzelli C., Vandecasteele I., Barranco R.R., Rivero I.M., Pelletier N., Batelaan O., Lavalle C.: Scenarios for shale gas development and their related land use impacts in the Baltic Basin, Northern Poland, Energy Policy, 84, 2015, pp. 80-95.

[3] Barron A.R., Skala R.D., Coker C.E., Chatterjee, D.K., Xie Y.: Method of Manufacture and the Use of a Functional Proppant for Determination of Subterranean Fracture Geometries, Patent US 2009/0288820 A1, 2009.

[4] Barron A.R., Tour J., Busnaina A., Jung Y., Somu S., Kajn M., Potter D., Resanco D., Ullo J.:Big things in small packages, Oilfield Review. 22 (3), 2010, pp. 38-49. 
[5] Barron A.R., Potter D.K., Maguire-Boyle S.J., Pena E., Morrow L.: Methods, Apparatus, and Sensors for Publication Classification Tracing Frac Fluids in Mineral Formations, Production Waters, and the Environment Using Magnetic Particles, Patent US 2014/0357534 A1, 2014.

[6] Bicerano J.: Proppants Coated with Piezoelectric or Magnetostrictive Materials, or by Mixtures or Combinations Thereof, to Enable Their Tracking in a Downhole Environment, Patent no US 2010/0038083 A1, 2010.

[7] Bogacki J., Zawadzki J.: The influence of ferrite particle size on the quality of the magnetic marker in shale gas hydraulic fracturing, Systemy wspomagania w inżynieri iprodukcji. Review of problems and solutions, 3 (15), 2016, pp. 25-33.

[8] Borglin S.E., Moridis G.J., Becker A.: Magnetic Detection of Ferrofluid Injection Zones. Lawrence Berkley National Laboratory, Berkley, 1998.

[9] Byerlee, J.D., Johnston, M.J.S.: A magnetic method for determining the geometry of hydraulic fractures, Pageoph 114, 1976, pp. 425-433.

[10] Chen S.: Precision Making of Subsurface Locations, Patent no US 2012/0234533 A1, 2012.

[11] Cocuzza M., Pirri C., Rocca V., Verga F.: Current and future nanotech applications in the oil industry. American Journal of Applied Sciences. 9 (6), 2012, pp. 784-793.

[12] Curtis J.B.: Fractured shale-gas systems, AAPG Bulletin, 86, 2002, pp. 1921-1938.

[13] Ersoz H.V.: Use of Magnetic Liquids for Imaging and Mapping Porous Subterranean Formations, Patent US 2014/0041862 A1, 2014.

[14] Fabijańczyk P., Zawadzki J., Magiera T., Szuszkiewicz M.: A methodology of integration of magnetometric and geochemical soil contamination measurements, Geoderma 277, 2016, pp. 51-60.

[15] Ferronato M., Gambolati G., Teatini P., Baù D.: Radioactive marker measurements in heterogeneous reservoirs: numerical study, International Journal of Geomechanics. 79, 2004, pp. 79-92.

[16] Frycz M.: Wpływ temperatury i stężenia cząstek magnetycznych Fe3O4 na wartość gęstości ferrocieczy wykonanej na bazie oleju silnikowego, Zeszyty Naukowe Akademii Morskiej w Gdyni, 64, 2010, pp. 51-58.

[17] Gandossi L.: An Overview of Hydraulic Fracturing and Other Formation Stimulation Technologies for Shale Gas Production, Report EUR 26347 EN, Institute for Energy and Transport, European Commission, 2013.

[18] Giakisikli G., Anthemidis A.N.: Magnetic materials as sorbents for metal/metalloid preconcentration and/or separation. A review, Analytica Chimica Acta, 789, 2013, pp. 1-16.

[19] Guire de E.: Shale gas recovery-Engineering a big business, American Ceramic Society Bulletin, 93 (1), 2014, pp. 27.

[20] Henley D.,: Process for single system electrocoagulation, magnetic, cavitation and flocculation (EMC/F) treatment of water and wastewater, Patent US 2013/0161262 A1, 2013.

[21] Huh C., Nizamidin N., Pope G.A., Milner T.E., Wang B.: Hydrophobic Paramagnetic Nanoparticles as Intelligent Crude Oil Tracers, Patent WO 2014123672A1, 2014. 
[22] Javadpour F., Fisher D., Unsworth M.,: Nanoscale Gas Flow in Shale Gas Sediments, Journal Of Canadian Petroleum Technology, 46, 2007, pp. 55-61.

[23] Konieczyńska M., Woźnicka M., Antolak O., Janica R., Lichtarski G., Nidental M., Otwinowski J., Starzycka A., Stec B., Grzegorz W.: Badania Aspektów Środowiskowych Procesu Szczelinowania Hydraulicznego Wykonanego W Otworze Łebień LE-2H, Państwowy Instytut Geologiczny, Warszawa, 2011.

[24] Liang F., Sayed M., Al-Muntasheri G.A., Chang F.F., Li L.: A comprehensive review on proppant technologies, Petroleum 2015, pp. 1-14.

[25] Magiera T., Zawadzki J.: Magnetometria glebowa - nowe narzędzie geofizyczne do oceny zanieczyszczenia gleb, Geofizyka. Biuletyn Informacyjny PBG, 2, 2006, pp. 74-90.

[26] Maramatsu S., Takasugi S., Osato K.,: Three-dimensional Detection System for Detecting Fractures and Their Distribution in the Earth Crust Utilizing an Artificial Magnetic Field and Magnetic Particle Tracer, US Patent No. 5151658, 1992.

[27] Meng Q.: Spatial analysis of environment and population at risk of natural gas fracking in the state of Pennsylvania, USA, Science if the Total Environment 515516, 2015, pp. 198-206.

[28] Meyer T.J.: Mapping and Monitoring of Hydraulic Fractures Using Vector Magnetometers, Patent US 2015/0268373 A1, 2015.

[29] Morrow L., Potter D.K., Barron A.R.: Detection of magnetic nanoparticles against proppant and shale reservoir rocks, Journal of Experimental Nanoscience. 10 (13), 2014, pp. 1028-1041.

[30] Munoz M., de Pedro Z.M., Casas J.A., Rodriguez, J.J.: Preparation of magnetitebased catalysts and their application in heterogeneous Fenton oxidation - A review, Applied Catalysis B: Environmental, 176-177, 2015, pp. 249-265.

[31] Nguyen, P.D., Weaver, J.D., Bartom, J.A.: Method of Tracking Fluids Produced from Various Zones in Subterranean Wells. Patent US 6,725,926 B2, 2004.

[32] Norena L.E., Wang J.A.: Advanced Catalytic Materials - Photocatalysis and Other Current Trends, InTech, DOI: 10.5772/60491, 2016.

[33] Pękala A., Głowienka E.: Badania korelacji pierwiastków śladowych w środowisku glebowo-roślinnym przy zastosowaniu metod GIS, Czasopismo Inżynierii Lądowej, Środowiska i Architektury - Journal of Civil Engineering, Environment and Architecture, JCEEA, 63 (2), 2016, pp. 209-219, DOI: 10.7862/rb.2016.123.

[34] Potter D.K., Barron A.R., Maguire-Boyle S.J., Orbaek A.W., Ali A., Harrison L.: Magnetic Particles for Determining Reservoir Parameters, PatentWO2011153339, 2011.

[35] Rogala A., Krzysiek J., Bernaciak M., Hupka J.:Non-aqueous fracturing technologies for shale gas recovery, Physicochemical Problems of Mineral Processing. 49 (1), 2013, pp. 313-322.

[36] Saaba B.: Potential Treatment Options for Hydraulic Fracturing Return Fluids: A Review, ChemBioEng Reviws. 1 (6), 2014, pp. 273-279.

[37] Strzyszcz Z.: Magnetic susceptibility of soils in the areas influenced by industrial emissions. [W]: R. Schulin (Ed.), Soil Monitoring. Monte Verita. Birkhäuser Verlag, Basel, 1993, pp. 255-269. 
[38] Strzyszcz Z., MagieraT., Heller F.: The influence of industrial emissions on the magnetic susceptibility of soils in Upper Silesia, Studia Geophysica et Geodaetica. 40, 1996, pp. 276-286.

[39] Strzyszcz Z., Magiera T.: Heavy metal contamination and magnetic susceptibility in soils of southern Poland, Physics and Chemistry of the Earth. 23, 1998, pp. 1127-1131.

[40] Strzyszcz Z., Magiera T.: Chemical and mineralogical composition of some ferromagnetic minerals occurring in industrial dusts and contaminated soils, Mitteilungen der DeutschenBodenkundlischen Gesellschaft, Bd.96 (H.2), 2001a, pp. 697-698.

[41] Strzyszcz Z., Magiera T.: Magnetic susceptibility measurement on ombrothrophic peat in monitoring of industrial immision, Archives of Environmental Protection. 27, 2001b, pp. 141-167.

[42] United States House of Representatives Committee on Energy and Commerce Minority Staff, Chemicals Used in Hydraulic Fracturing, 2011.

[43] Urbanik M., Tchórzewska-Cieślak B.: Ecological aspects of the natural gas use, Czasopismo Inżynierii Lądowej, Środowiska i Architektury - Journal of Civil Engineering, Environment and Architecture, JCEEA, 62 (1), 2015, pp. 409-417, DOI: $10.7862 / \mathrm{rb} .2015 .29$.

[44] US EPA Plan to Study the Potential Impacts of Hydraulic Fracturing on Drinking Water Resources, US Environmental Protection Agency, Office of Research and Development, Washington, D.C, 2011.

[45] Wilt M., Sen P.,: Electromagnetic Imaging of Proppant in Inducted Fracturing, Patent US 2014/0374091A1, 2014.

[46] Yuan J., Luo D., Feng L.: A review of the technical and economic evaluation techniques for shale gas development, Applied Energy 148, 2015, pp. 49-65.

[47] Zawadzki J.: Metody geostatystyczne dla kierunków przyrodniczych i technicznych, Oficyna Wydawnicza Politechniki Warszawskiej, Warszawa, 2011.

[48] Zawadzki J.: Wykorzystanie metod geostatycznych w badaniach środowiska przyrodniczego, Prace Naukowe Politechniki Warszawskiej. Inżynieria Środowiska, 3-134, Oficyna Wydawnicza Politechniki Warszawskiej, Warszawa, 2005.

[49] Zawadzki J., Bogacki J.: Rozwój technologii magnetycznych w wydobyciu gazu łupkowego, Systemy wspomagania w inżynierii produkcji. Górnictwo, Perspektywy i zagrożenia 1 (13), 2016a, pp. 25-37.

[50] Zawadzki J., Bogacki J.: Smart magnetic markers use in hydraulic fracturing, Chemosphere, 162, 2016b, pp. 23-30.

[51] Zawadzki J., Bogacki J.: On the possibility of magnetic nano-markers use for hydraulic fracturing in shale gas mining, Geophysical Research Abstracts. 18. 2016c, EGU2016-6749-1.

[52] Zawadzki J., Fabijańczyk P., Magiera T., Rachwał M.: Geostatistical microscale study of magnetic susceptibility in soil profile and magnetic indicators of potential soil pollution. Water, Air, \& Soil Pollution 226 (5), 2015, pp. 1-8. 


\section{ZASTOSOWANIE MARKERÓW MAGNETYCZNYCH DO MONITORINGU ZANIECZYSZCZENIA ŚRODOWISKA PŁYNEM SZCZELINUJĄCYM PODCZAS EKSPLOATACJI GAZU LUPKOWEGO}

\section{Streszczenie}

Materiały magnetyczne dodawane do płynu szczelinującego jako marker magnetyczny, mogą $\mathrm{w}$ procesie szczelinowania hydraulicznego pełnić dodatkowe funkcje, oprócz umożliwienia określenia zasięgu szczelin w skałach złożowych wytwarzanych w tym procesie. Ocenia się, że zastosowanie odpowiednich markerów magnetycznych może znacznie poprawić wydajność wydobycia gazu łupkowego. Istnieją jednakże inne, istotne korzyści z zastosowania markerów magnetycznych, polegające na monitoringu zanieczyszczenia środowiska $\mathrm{w}$ trakcie wydobycia gazu łupkowego omawianą metodą. Niestety, wraz z gwałtownym wzrostem ilości wydobywanego gazu łupkowego, z zastosowaniem metody szczelinowania hydraulicznego, pojawiły się również wiarygodne doniesienia o możliwości zanieczyszczenia wód podziemnych lub gleby, w trakcie tego procesu. Konieczne jest więc zastosowanie skutecznych metod wykrywania potencjalnego wycieku płynu szczelinującego. Stosowanie markerów magnetycznych daje takie możliwości. W przypadku wystąpienia wycieku i w konsekwencji zanieczyszczenia środowiska płynem szczelinującym, również markery magnetyczne zostają wprowadzone do środowiska gruntowego. Obecność zanieczyszczeń $\mathrm{w}$ gruncie można stwierdzić za pomocą wielu standardowych metod chemicznych. Ze względu na znaczną czasochłonność i kosztochłonność bezpośrednich metod laboratoryjnych, na uwagę zasługują znacznie szybsze i tańsze metody magnetometryczne, które pozwalają na łatwe, in-situ, wykrycie markera magnetycznego w ewentualnym wycieku. W artykule omówione zostaną wspomniane powyżej zagadnienia na podstawie przeglądu literaturowego oraz wiedzy i doświadczenia autorów.

Słowa kluczowe: markery magnetyczne, gaz łupkowy, szczelinowanie hydrauliczne, zanieczyszczenie środowiska, metody magnetometryczne, podatność magnetyczna

Przestano do redakcji: 20.02.2017 r.

Przyjęto do druku: 28.04.2017 $r$. 